\title{
DIRECTION-ASYMMETRIC EQUIVALENCE IN LEGAL TRANSLATION ${ }^{1}$
}

\author{
TOMÁŠ DUBĚDA, Ph.D. \\ Institute of Translation Studies \\ Faculty of Arts, Charles University, Prague, Czech Republic \\ dubeda@ff.cuni.cz
}

ORCID: https://orcid.org/0000-0003-0609-4506

\begin{abstract}
The concept of equivalence, despite the criticism it has received in the past decades, remains a useful framework for the study of correspondence between legal terms. In the present article, I address the question of directionasymmetric equivalence in legal translation, i.e. equivalence that does not obey the "one-to-one" principle, and which usually implies that the translator's decision-making is more difficult in one direction than in the other. This asymmetry may be triggered by intrinsic semantic characteristics of legal terms (synonymy and polysemy), by differences between legal systems (systemspecific terms, the procedures used for their translation and their handling in lexicographic sources, competing legal systems, tension between cultural boundedness and neutrality), or by social factors (L1 vs. L2 translation). The
\end{abstract}

\footnotetext{
${ }^{1}$ Acknowledgement: This research was supported by the Charles University project Progres Q10, "Language in the shiftings of time, space, and culture".
} 
instances of directional asymmetry discussed are illustrated with examples from French and Czech.

Keywords: legal translation; legal terminology; equivalence; translation direction; French; Czech; languages with limited diffusion.

\section{SMĚROVĚ ASYMETRICKÁ EKVIVALENCE V PRÁVNÍM PŘEKLADU}

Resumé: Pojem ekvivalence je i přes kritiku, jíž byl vystaven v posledních desetiletích, užitečným rámcem pro studium korespondence mezi právními termíny. V tomto článku se zabývám otázkou směrově asymetrické ekvivalence v právním překladu, tj. ekvivalence, která nesplňuje požadavek korespondence ,jedna ku jedné“. Rozhodovací procesy jsou u tohoto typu ekvivalence obvykle v jednom směru náročnější než ve druhém. Směrová asymetrie může být vyvolána inherentními sémantickými vlastnostmi právních termínů (synonymie a polysémie), rozdíly mezi právními systémy (systémově specifické termíny, překladatelské postupy užívané $\mathrm{k}$ jejich překladu a jejich zpracování v lexikografických zdrojích, konkurenční právní systémy, napětí mezi kulturní vázaností a neutrálností) nebo sociálními faktory (překlad do mateřského vs. cizího jazyka). Jednotlivé typy směrové asymetrie jsou ilustrovány na př́kladech z francouzštiny a češtiny.

Klíčová slova: právní překlad; právní terminologie; ekvivalence; směr překladu; francouzština; čeština; málo rozšířené jazyky.

\section{The concept of equivalence and the question of directionality}

In the early stages of modern translation science, equivalence was regarded as a central theoretical concept. This has to do with the fact that the discipline is rooted in applied linguistics, from which it received the initial impetus. The first major refinement of the concept of equivalence originates from Nida (1964), who, applying a functional perspective, differentiated between formal equivalence and dynamic (or functional) equivalence, the latter being defined by an "equivalent effect" on the receiver. Later on, with the shift of interest from language towards functional, social and cognitive aspects of translation, the concept of equivalence was pushed into the background, and some 
authors started emphasising its problematic nature: Snell-Hornby (1988: 22) considers that the analysis of equivalence may give a false impression of symmetry between languages, Larose (1989: 78) holds that it is virtually impossible to define the "equivalent effect", and Lefevere (1992: 7) points out the risk of reducing equivalence to a word-level phenomenon.

Most of this criticism came from the field of literary translation, while in the domain of specialised translation, the concept of equivalence remained in use, partly thanks to adjacent disciplines such as lexicology or terminology. Perfect one-to-one equivalence between lexical items in two languages is rare (although it can be observed in terminological systems, and, perhaps, between closely related languages such as Serbian and Croatian, or Czech and Slovak), but this does not undermine the usefulness of the concept itself. Catford (1965: 26) gives a purely descriptive definition of the translation equivalent: "any TL [target-language] text or portion of text which is observed on a particular occasion... to be the equivalent of a given SL [sourcelanguage] text or portion of text." This approach is theoretically interesting, because it allows for different types of equivalence (e.g. formal vs. functional, lexical vs. textual, etc.), as well as different degrees of equivalence (e.g. full vs. partial). On the practical level, it should not be forgotten that the translation process is, in fact, an incessant search for optimal equivalence.

With respect to directionality, Pym (2010) differentiates between natural equivalence (one-to-one relationship between equivalents in two languages) and directional equivalence (one-tomany relationship). These two types of equivalence can be distinguished from one another by means of the back-translation test: while natural equivalence returns the original wording, directional equivalence may lead to a different rendering. It is evident that the "oneto-many" situation largely prevails in the translation process. Indeed, theoretical concepts such as formal vs. functional equivalence (Nida 1962), documentary vs. instrumental translation (Nord 2005), explicitation vs. implicitation (Klaudy 2009) and many others can only be meaningful if we admit that translation includes a choice between several options. 


\section{Types of equivalence in legal terminology}

The discourse about equivalence in legal translation is - quite understandably - biased towards terminology. According to Cao (2007: 53), "[1]egal terminology is the most visible and striking linguistic feature of legal language as a technical language." A detailed classification of equivalent types in legal terminology, taking into account both the type and the degree of equivalence, was proposed by Šarčević (1997). This system, appreciated for its comprehensiveness, is frequently referred to by other authors writing on the subject (e.g. Cao 2007; Chromá 2014). In my own article (Duběda 2021), I attempt a critical survey of equivalence types found in literature on legal translation. The analysis reveals more than 30 different labels (e.g. natural, functional, semantic, linguistic, formal, literal, archaic, etymological, borrowing, neologism, lexical specification, etc.), some of them being synonymous or quasi-synonymous with others, and some differing in their definition across authors. I propose a detailed, multidimensional typology of legal equivalents, using four orthogonal criteria: translation procedure, degree of equivalence, conventionality and register. Translation procedures can be arranged on a scale running between function-oriented strategies and language-oriented strategies.

An additional question, briefly discussed in Duběda (2021), is that of directional symmetry vs. asymmetry of legal equivalents. It has been shown in Section 1 that this issue is not limited to legal translation, but is transversal to all translation fields. In the following section, I endeavour to apply this question to legal translation, identifying six areas where it is relevant. The common denominator of all these instances is the asymmetry of two terminological systems, usually with the implication that the translator's decision-making is more difficult in one direction than in the other and that the back-translation is less likely to result in the original term. The discussion is accompanied by illustrative examples from French and Czech. 


\section{Aspects of direction-asymmetric equivalence in legal translation}

\subsection{Synonymy and polysemy}

The synonymy and polysemy of legal terms, discussed e.g. by Chromá (2011), represents probably the most obvious deviation from the "oneto-one" correspondence principle. It is interesting to note that even in such a technical and heavily regulated area as law, the matching between concepts and terms is very often not straightforward. For the translator, synonymy involves at least three specific challenges:

1. Identifying terms which are synonymous or used as synonyms: For example, the terms vente 'sale' and cession 'assignment' are often used interchangeably in French sales contracts, although the latter is a hypernym of the former, and it is preferable to translate them both into Czech by the more idiomatic term prodej 'sale'. A specific case of textual synonymy is represented by legal couplets such as à ses risques et périls 'at his/her own risk and peril'. Unlike legal English, in which these structures are notoriously common (Cao 2007: 89), they are much less frequent in legal French, and may be thus wrongly interpreted as pairs of semantically different expressions.

2. Coping with partial synonymy:

For example, the Czech term právo 'right, law' is often interchangeable with oprávněni 'right, entitlement', except for the objective meaning 'law', where oprávněni can never be used.

3. Choosing the most adequate of two or more synonyms or nearsynonyms with respect to register and text type:

For example, the French family law term adoption 'adoption' can be translated into Czech as osvojeni or adopce, the former equivalent occurring especially in statutes and judgements, and the latter being used in less formal or scientific texts. The stylistic value of legal terms is a relatively understudied phenomenon, possibly because of the assumption that terminology is stylistically neutral. This assumption turns out not to be fully true (Duběda 2021), especially in legal Czech, 
Tomáš Duběda: Direction-Asymmetric Equivalence In Legal ...

whose typical feature is the co-existence of native terms and internationalisms (účinek/efekt 'effect'; úvěr/kredit 'credit'; výklad/interpretace 'interpretation').

As for polysemy, translators face several types of difficulties:

1. Distinguishing general meaning from legal meaning:

For example, the general meaning of the French term information is 'information', while the legal meaning of this term in criminal law is 'investigation'.

2. Identifying field-specific meaning:

For example, the French term auteur takes the meaning 'author' in copyright law, 'offender' in criminal law, and 'legal predecessor' in civil law.

3. Coping with semantic compatibility and collocability:

For example, the Czech expression prihláška 'application' may translate into French in various ways, which are only partly interchangeable: inscription, candidature, formulaire d'inscription, bulletin d'adhésion, dossier de candidature etc. Other contextual equivalents are used in collocations: patentová prihláška - demande de brevet 'patent application', přihláška pohledávky - déclaration de créance 'claim submission'.

\subsection{System-specific terms}

Legal language is intimately connected with the legal system it serves (Šarčević 1997: 14). It follows from this that, when translating between two languages, one often encounters concepts that only have an authentic existence in one of the languages, and not in the other. Where no acceptable functional equivalent is available in the other language, such terms must be translated by means of other procedures (literal translation, lexical specification, borrowing, etc.). For example, the Czech concept of vrchni soud 'High Court' (appellate court for cases heard in first instance by Regional Courts) does not exist in French law; therefore, the term is mostly translated literally as cour supérieure. For a French lawyer, this term stands out as denoting a foreign concept. 
With respect to translation direction, a characteristic feature of system-specific terms is that they are mostly translated out of the language to which they belong, and only sporadically in the opposite direction. Nonetheless, this latter situation does occur in translation practice: it can be illustrated, for example, by a French judicial decision containing references to Czech law that have been previously translated from Czech into French. When translating such a decision into Czech, the translator faces particular difficulties: he or she has to imagine the translation procedure used by the first translator, i.e. the one who translated Czech legal terms into French, and find the correct backtranslation into Czech. Unlike in translation into French, where several target equivalents are potentially acceptable, the back-translation should ideally result in one correct equivalent. Of course, the translator's task is much facilitated if the references to Czech law are available in their original version, or if the first translator has added original Czech terms in brackets, e.g. cour supérieure (vrchni soud). This is, however, not always the case.

System-specific terms also have implications for bilingual lexicography: bidirectional dictionaries of legal language are usually asymmetric in the sense that system-specific terms are only listed in one direction, i.e. they do not cover the back-translation situation described above. In her book describing the genesis of a Czech-English law dictionary, Chromá (2004: 71) presents the sources used for the constitution of the corpus of Czech headwords. It is noteworthy that she only mentions monolingual sources (Czech legislation, law textbooks, contracts, monolingual law dictionaries, etc.), but not her EnglishCzech dictionary, which she had published a few years earlier, and which could have served as an initial source of headwords. In the same vein, De Groot and Van Laer (2006) claim that "[r]eversing the functions of source terms and their partial equivalents, descriptions or neologisms will create false translation suggestions."

It can be reasonably argued that a reversed list of headwords and equivalents can be used as an intermediate product in the elaboration of a bidirectional dictionary, since a significant part of legal terms found in European legal systems are functional equivalents working in both directions, thus testifying to the existence of a "common core" of legal systems (Schlesinger 1980: 36). Of course, this claim is valid especially within legal families (Civil Law and Common Law), and less so across them. However, a professional legal dictionary should be free of unnecessary or misleading entries. To give one 
example, the standard French-Czech and Czech-French legal dictionary (Larišová 2008) occasionally uses a simple reversal of equivalents in the Czech-French part: in the entry státni zástupce 'prosecuting attorney', five French equivalents are given, four corresponding to French concepts and one to a Belgian concept; some of these equivalents are specified as to the French court to which the given attorney is attached. On the other hand, Czech phrases such as okresni státní zástupce 'district prosecuting attorney', nejvyššsi státní zástupce 'attorney general' etc., that a user would expect in the Czech-French part of the dictionary, are not included in this entry.

With the gradual shift from paper dictionaries towards searchable online resources (Nielsen 2014), the question of lexicographic symmetry vs. asymmetry comes to the fore in a new context. Since an electronic dictionary usually comprises a single database covering both directions, specific approaches are needed to ensure that each search will return the expected results. For instance, Nielsen (2014) describes a repository of Danish-English data connected to several interfaces, each designed for a specific task (e.g. understanding a Danish legal text, writing an English legal text, translating a legal text from English into Danish, translating a legal text from Danish into English, etc.). The French-Czech database of legal language LEGILEX-FR, while offering a single interface for searches in both directions, provides system-specific equivalents with explicit labels, e.g. Cour de cassation (FR) - Kasačni soud 'Court of Cassation'; tribunal cantonal $(\mathrm{CH})$ - kantonálni soud 'Cantonal Court'; katastrální úřad (CZ) - bureau du cadastre 'Land Registry' (FR standing for French law, $\mathrm{CH}$ for Swiss law, and $\mathrm{CZ}$ for Czech law).

Both aforementioned tools also illustrate another tendency: online lexical databases tend to fulfil a larger spectrum of functions than a conventional dictionary. Because of the absence of space limitations and the possibility of adding web references, online lexicographic tools may contain definitions, references to legislation and other documents, remarks on comparative law, real-time corpus search etc. This additional information helps the translator fully understand the term in question, including its directional sensitivity, and make informed decisions both in interpreting the source text and compiling the target text. 


\subsection{Translation procedures used for system-specific terms}

Not only are system-specific terms strongly correlated with one translation direction, but they are also distinct from other terms with respect to the translation procedures they call for. Most of the equivalence types mentioned in section 2 - with the exception of functional equivalence - are, in fact, used precisely to overcome difficulties with system-specific terms. More often than not, the translator has to choose between two or more possible translation procedures, which may yield different results as to the documentary vs. instrumental character of the target equivalent.

For instance, in the French legal system, the term projet de loi denotes a bill introduced by the Government, while proposition de loi is a bill introduced by the Parliament, and there is no simple way of expressing the meaning 'bill' without this distinction. By contrast, Czech offers such a term: návrh zákona. Where the distinction is to be preserved, the target term must be lexically specified by an adjective: projet de loi - vládní návrh zákona; proposition de loi - parlamentní návrh zákona. The back-translation of these terms involves a potential risk: if the translator is not conscious of the exact semantic value of projet and proposition in this context, he or she may translate vládni návrh zákona literally as projet de loi gouvernemental, which is not wrong per se, but somewhat less idiomatic, or as proposition de loi gouvernementale, which is, strictly speaking, an oxymoron. Another option for translating the term projet de loi is leaving out the specification, and using the more general term návrh zákona. This leads to a possibly more authentic equivalent, which is a good candidate especially if it can be inferred from the context that the bill was introduced by the Government. The back-translation, however, is more risky than in the previous case: the translator not only has to be familiar with the distinction projet vs. proposition, but also has to analyse the context in order to choose the right equivalent.

The translation procedures discussed in the previous paragraph - lexical specification and generalisation - are only two of the many ways equivalence can be achieved, yet they are representative of two opposing approaches. Lexical specification is a documentary procedure, which tends to render the exact lexical meaning and may lead to a less idiomatic result, while generalisation is an instrumental 
procedure, which grasps the functional aspects of the term and yields better idiomacy. Documentary strategies, which also include literal translation, borrowings or calques, seem to prevail in the practice of sworn translators and translators of official texts (Mayoral Asensio 2003: 42; Franco Aixelá 2009). They are often deemed safer, because they involve less interpretation, and their use is also encouraged by law dictionaries, whose perspective is necessarily term-centred and which tend to favour periphrastic and definition-like equivalents. Instrumental strategies, on the other hand, tend to make the best of functional equivalence, be it only partial, preferring readability, intelligibility and target-language stylistic conventions. They have also acquired a place in bilingual legislation (Dullion 2007; Gémar 2015), their potential lack of precision being countered by terminological consistency and uniform interpretation of the language versions.

\subsection{Competing legal systems}

A special category of terminological synonymy is the coexistence of two or more terms denoting the same concept, but pertaining to different legal systems. For example, the terms droit pénal and droit criminel denote the same concept ('criminal law'), the former being used in European legal French, and the latter in Canadian legal French. A translator working into a language used in more than one legal systems should, optimally, be aware of terminological differences between these varieties of legal language, and remain consistent in his or her terminological choices. As far as the language pair French - Czech is concerned, however, at least two complicating circumstances are worth mentioning:

1. Asymmetry due to the translator's legal background:

A French translator and a Swiss translator translating a Czech legal text into French in their respective countries will quite naturally use their national legal system as reference, and produce two partly different versions of this text. Czech translators, on the other hand, are mostly trained in the legal terminology used in France, and less so in the terminology of other francophone systems. Adhering to legal terminology of 
French law, with its major historical role, international impact and prominent position in teaching, is thus the default practice in the Czech Republic, and also in many other European countries. This bias can be expected in translations for any kind of French speaking public.

2. Terminological hybridisation:

Despite the prevalent use of French law as a reference system for terminology, some system-specific terms of Czech law a better translated with terms taken from other francophone systems. For example, the nearest functional equivalent of registrované partnerstvi 'registered partnership' in French law is pacte civil de solidarité (PACS). This equivalent, however, is not an ideal candidate, since it implies one major legal difference (registrované partnerství is defined as a same-sex partnership, while $P A C S$ can be concluded by both same-sex and different-sex couples), it emphasises rather specific legal aspects of the union (its contractual and civil character, and the obligation of solidarity), and is generally regarded as a French cultural phenomenon. The Swiss term partenariat enregistré, on the other hand, has the advantage of being a functional, literal and fairly neutral equivalent. Using a third system as a source of equivalents is one of the recognised procedures in legal translation (Šarčević 1997: 263).

\subsection{Cultural boundedness vs. neutrality}

As Šarčević (1997: 241) tellingly puts it, "it sometimes occurs that A can be used to translate B, but B cannot be used to translate A." In the preceding section, I discussed the Czech term registrované partnerstvi 'registered partnership', which is better translated into French by the more neutral term partenariat enregistré than by the specifically French term pacte civil de solidarité. The question arises, then, how to translate the French term pacte civil de solidarité into Czech. The legal dictionary (Larišová 2008) gives the literal translation občanská smlouva o solidarité, which is considerably opaque to a Czech reader. By contrast, Tomaščínová (2019) renders this terms with the functional equivalent registrované partnerství, adding the remark 
"approximately". The functional equivalent is easily interpretable, though less precise due to the aforementioned difference in legal definition. In my view, however, it is by no means wrong to translate pacte civil de solidarité as registrované partnerství, just as it is not wrong to translate mariage by manželstvi 'marriage', although the French concept extends to same-sex marriage, while the Czech does not. This reasoning leads to the - apparently paradoxical - conclusion that pacte civil de solidarité can be translated by registrované partnerství, but registrované partnerstvi should not be translated by pacte civil de solidarité. The asymmetry is, in reality, not paradoxical, because the two translation directions involve two different legal systems. In bilingual jurisdictions, of course, such discrepancies are to be avoided.

This specific instance of directional asymmetry occurs especially in situations where one of the arguments is the neutrality of an equivalent: partenariat enregistré and registrované partnerství are more neutral than pacte civil de solidarité and občanská smlouva o solidarite, and, as a consequence, the first two terms are more likely to be used as target equivalents than the last two, which triggers directional asymmetry. Another example may be the Czech administrative unit kraj 'region', translated into French uniformly as région. On the other hand, the French administrative unit région is translated into Czech variably as kraj or region. The latter equivalent, having a looser link to Czech reality, is more neutral, which makes it an acceptable, and perhaps better, candidate.

\subsection{L1 vs. L2 translators}

In many countries whose language is a language of low diffusion, local translators are entrusted on a regular basis with non-literary translations into major international languages such as English or French (Prunč 2000; Pavlović 2007; Duběda 2018). In these countries, L2 translation (i.e. translation into the translator's foreign language) is mostly not regarded as an unprofessional practice, but rather a pragmatic response to the lack of L1 translators. L2 translation seems to be particularly frequent in the field of law: for example, the Czech Sworn Interpreters and Translators Act makes no distinction between the two translation 
directions, and, as a consequence, a sworn translator working for public administration cannot refuse an assignment on the grounds that he or she is not willing to translate into a foreign language.

In a recent investigation into the quality of legal translation (Duběda et al. 2018: 78), it has been confirmed that the overall quality of L2 translations is worse than that of L1 translations. If we combine this rather obvious finding with the fact that a vast majority of legal translations from Czech into French are made by non-native translators based in the Czech Republic, we come to the somewhat worrying conclusion that the translation quality is inherently lower in one direction than in the other. With respect to equivalent choice, practice shows that L2 translation involves a higher proportion of linguistically deficient solutions, a greater propensity towards literal renderings, and a greater inter-translator variability. These features have also been observed in a survey carried out among Czech sworn translators (Duběda 2020), whose aim was to provide an insight into the way in which Czech system-specific legal terms are translated into French. However, the survey does not provide a direct comparison of L1 and L2 translations, since all participants but one were native speakers of Czech.

\section{Conclusion}

In the preceding paragraphs, I have developed the question of directional asymmetry in six different contexts relevant for legal translation. Some instances of this asymmetry have to do with intrinsic semantic characteristics of the terms (synonymy and polysemy), others are triggered by differences between legal systems (system-specific terms, the procedures used for their translation and their handling in lexicographic sources, competing legal systems, tension between cultural boundedness and neutrality), and yet others are socially determined (L1 vs. L2 translators).

The claim that terminology is a relatively unproblematic area of legal translation is nowadays refuted by both scholars and practitioners. The present analysis brings further evidence of the complicated nature of legal equivalence, which constitutes a challenging aspect of the translators' decision-making. The question is 
particularly acute in the case of "bidirectional" translators, i.e. translators working both into their mother tongue and from it. These translators must bear in mind that strategies to achieve equivalence may be direction-sensitive, and that their lesser proficiency in the target language may have an impact on translation quality and security. Both of these caveats should also have their place in translator training.

The translation examples used in this article include French and Czech - two languages whose international diffusion differs dramatically, with all the consequences that it entails for the sociology of French-Czech and Czech-French legal translation. It goes without saying that some of the proposed conclusions also apply to other European countries whose official language is a language of low diffusion.

The purpose of this article was to shed more light on one of the problematic aspects of legal equivalence, namely its directional asymmetry. This does not mean, however, that the concept of equivalence as such is to be avoided: different types and degrees of equivalence can be achieved by different means, depending on the function of the translated text. As Cao (2007: 59) points out, "[i]t is futile to search for absolute equivalence when translating legal concepts." Notwithstanding that, it is beyond any doubt that legal translators are capable of producing translations that serve their purpose.

\section{References}

Cao, Deborah. 2007. Translating Law. Clevedon - Buffalo - Toronto: Multilingual Matters.

Catford, John C. 1965. A Linguistic Theory of Translation. An Essay in Applied Linguistics. Oxford: Oxford University Press.

Chromá, Marta. 2004. Legal Translation and the Dictionary. Tübingen: Max Niemeyer Verlag.

Chromá, Marta. 2011. Synonymy and Polysemy in Legal Terminology and Their Applications to Bilingual and Bijural Translation. Research in Language 9/1: 31-50.

Chromá, Marta. 2014. Právní překlad v teorii a praxi. Nový občanský zákoník. Praha: Karolinum. 
De Groot, Gerard-René, and Conrad J. P. van Laer, 2006. The Dubious Quality of Legal Dictionaries. International Journal of Legal Information 34/1: 65-86.

Duběda, Tomáš. 2018. La traduction vers une langue étrangère : compétences, attitudes, contexte social. Meta 63/2: 492-509.

Duběda, Tomáš. 2020. Soudní překladatelé a terminologické nástrahy. Průzkum $\mathrm{k}$ překladu právních termínů $\mathrm{z}$ češtiny do francouzštiny. Soudni tlumočník 2/2020: 25-28.

Duběda, Tomáš. 2021. K typologii ekvivalenti̊ v právním překladu. Slovo a slovesnost 82/2: 139-158.

Duběda, Tomáš, David Mraček, and Vanda, Obdržálková. 2018. Překlad do nemateřského jazyka: fakta, otázky, perspektivy. Praha: Karolinum.

Dullion, Valérie. 2007. Traduire les lois. Un éclairage culturel. La traduction en français des codes civils allemand et suisse autour de 1900. Cortil-Wodon: E. M. E.

Franco Aixelá, Javier. 2009. An overview of interference in scientific and technical translation. JoSTrans, The Journal of Specialised Translation 11: 75-87.

Gémar, Jean-Claude. 2015. De la traduction juridique à la jurilinguistique : la quête de l'équivalence. Meta 60/3: 476-493.

Klaudy, Kinga. 2009. The Asymmetry Hypothesis in Translation Research. In Translators and their readers. In Homage to Eugene A. Nida, eds. Rodica Dimitriu and Miriam Shlesinger, 283-303. Brussels: Les Editions du Hazard.

Larišová, Markéta. 2008. Francouzsko-český, česko-francouzský právnický slovnik. Plzeň: Aleš Čeněk.

Larose, Robert. 1989. Théories contemporaines de la traduction. Québec: Presses de 1'Université du Québec.

Lefevere, André. 1992. Translating Literature: Practice and Theory in a Comparative Literature Framework. New York: MLA.

Mayoral Asensio, Roberto. 2003. Translating Official Documents. London - New York: Routledge.

Nida, Eugene A. 1964. Towards a Science of Translating: With Special Reference to Principles and Procedures Involved in Bible Translating. Leiden: Brill.

Nielsen, Sandro. 2014. Database of Legal Terms for Communicative and Knowledge Information Tools. In Legal Lexicography. A Comparative Perspective, ed. Máirtín Mac Aodha, 153-175. Farnham: Ashgate. 
Nord, Christiane. 2005. Text Analysis in Translation. Amsterdam - New York: Rodopi.

Pavlović, Nataša. 2007. Directionality in translation and interpreting practice. Report on a questionnaire survey in Croatia. Forum 5/2: 79-99.

Prunč, Erich. 2000. Translation in die Nicht-Muttersprache und Translationskultur. In Translation into Non-Mother Tongues: In Professional Practice and Training, eds. Meta Grosman, Mira Kadrić, Irena Kovačič and Mary Snell-Hornby, 5-20. Tübingen: Stauffenburg.

Pym, Anthony. 2010. Exploring Translation Theories. London - New York: Routledge.

Schlesinger, Rudolf. 1980. Comparative Law: Cases-Text-Materials. Mineola: Foundation Press.

Snell-Hornby, Mary. 1988. Translation Studies. An Integrated Approach. Amsterdam - Philadelphia: Benjamins.

Šarčević, Susan. 1997. New Approach to Legal Translation. The Hague - London - Boston: Kluwer Law International.

Tomaščínová, Jana. 2019. Úvod do právnické francouzštiny 1, 2. Praha: Karolinum.

\section{Online resources}

LEGILEX-FR. http://lex.ff.cuni.cz/legilex-fr/Index (accessed April 2, 2021).

Sworn Interpreters and Translators Act, Act $\mathrm{Nr}$ 354/2019. https://www.zakonyprolidi.cz/cs/2019-354 (accessed April 11, 2021). 